\title{
演題番号 31
}

\section{CCAS 回路（心筋保護回路）の使用経験}

\author{
市立坦川病院 胸部外科人工心肺係
}

$$
\text { 黒田広 }
$$

同 胸部外科

$\begin{array}{lllll}\text { 青 } & \text { 秀 俊 久保田宏 } \\ \text { 村 上 忠 司 } & \end{array}$

$$
\begin{gathered}
\text { 北海道大学医学部 第二外科 } \\
\text { 酒 井 圭 輔 }
\end{gathered}
$$

くはじめに>

われわれは，このほどベントレー社のCCAS回 路, 寸なわち心筋保護回路を入手し, この回路シ ステムの冷却効果を実験，検討した結果，充分臨 林使用できることが判った。この回路を，昭和56 年 9 月から 57 年 5 月までの 45 症例の開心術に, 実 際に臨床使用した。このCCAS回路システムを紹 介するととるに，若干の知見を得たので報告する.

<回路システムの紹介>

この CCAS 回路システムは，心筋保萑液を谷器 からポンプで水水の容器内のクーリングコイルを 通して冷却, 注入するもので, 室温の心筇保護液 をシングルパスで邻却できるよになっている。 又，回路中に温度測定部が設けられており，注入

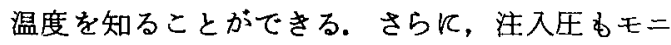
ターでき，注入口の手前には， 0.8 ミクロンのフィ ルターが付いて拐，混入したマイクロバブルを 除去することができる（図 1 )

写真 1 は, 水水の容器とスターラーである. 冷

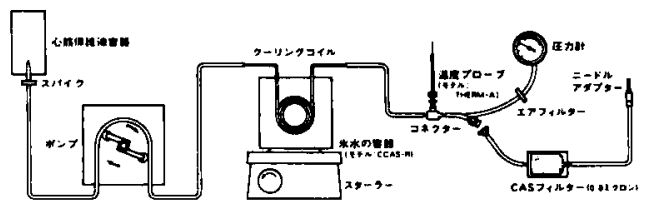

図 1 ペントレー心筋保護液注入システムCCAS



写怘 1

却効果を高めるため，スターラーで水水容器内を 霓找している。

写真 2 は，アルミのクーリングコイルで，心筋 保護液はこの中を通り冷却される. 冷却された液 は, Y字の温度測定部る通る。

そしてY字の一方は, 術野側回路に接続される。 他方は，注入時の压を測定する圧力計に接続され， その間には, エアフィルターが付いて扣り, 減菌 されていない厈力計にす使用できるようになって いる.（写真 3 ) 


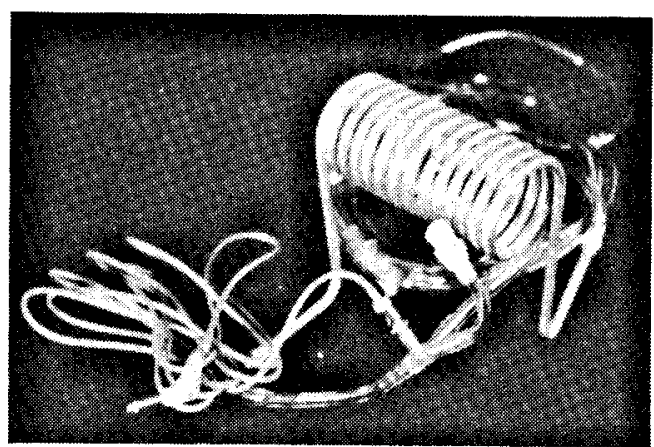

写真 2

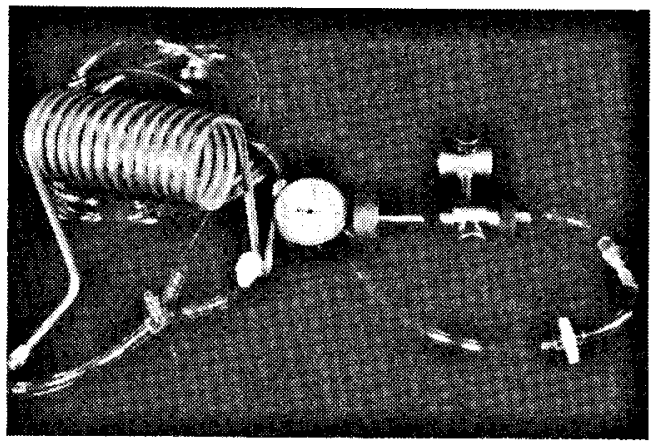

写真 3

写真 4 は, 術野側の CCAS 回路であるが， 0.8 ミクロンのフィルターが付いて扣り，心筋保護液 を汇過することができる。このフィルターは， 300 m $\mathrm{mg}$ 以上の圧がかかると液が漏れるので, 300 $\mathrm{mm} \mathrm{Hg}$ 以上の压をかけてはならない：又，0.8ミク



写真 4

ロンといら小さな孔のため，血液等の細胞成分を 含さ液は使用できないので注意が必要である。

军真は，手術時の回路を写したものである、ス ターラーの上に水水容器があり, その横に, ペン
トレーQ220のリザバーを置き，この中に心筇保 護液を入れている。また，リザーバーのプライミ ングロからチューブを入れ，そのチューブに酸素 を流し，心筋保護液に酸素付加をしている.

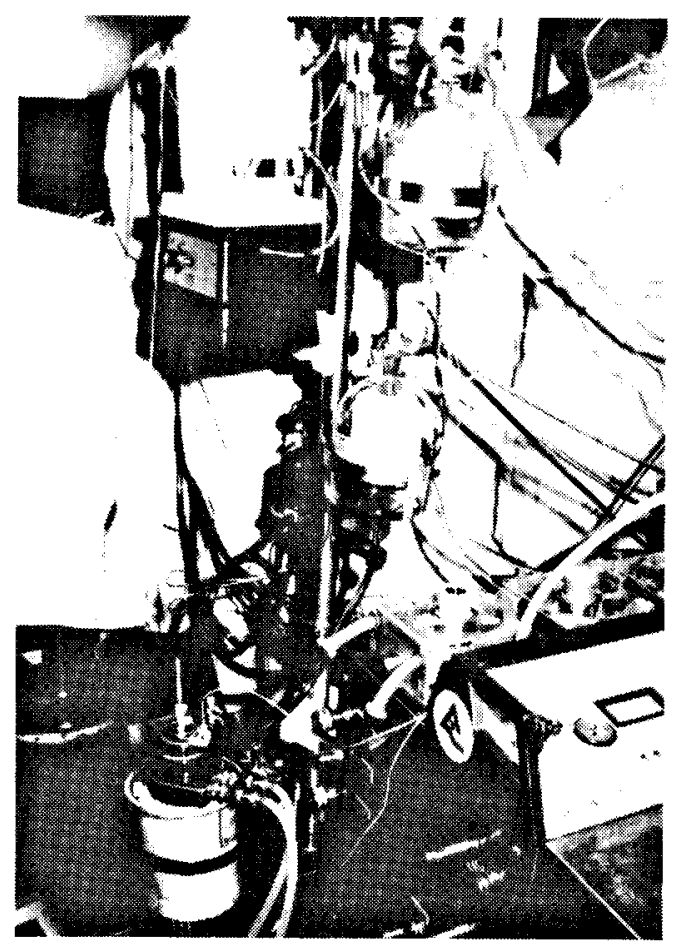

写真 5

$<$ 冷却害験 $>$

このCCAS 回路ジステムの玲却効果を検討する ために，冷却実験を行なった。，筋保護液は実際 に臨床に使用しているものを使用した。室温は24 ${ }^{\circ} \mathrm{C}$, 水水容器飞水 1.5 , , 水 1 とるれ, スター5 一をダイヤル 3 にして睍找した。温度測定部位は， 冷却前の心筋保護液, 擤拌されている水水容器内 の水温, クーリングコイルを通って泠却された心 筋保護液, 回路末端のニードルアダブターから出 てきた液の温度である.流量は $200 \mathrm{ml} / \mathrm{min}, 300$ $\mathrm{ml} / \min$ の 2 群として, 各測定部位で温度を測定 した. $200 \mathrm{ml} / \mathrm{min}$ では， $20^{\circ} \mathrm{C}$ の心筋保護液がク

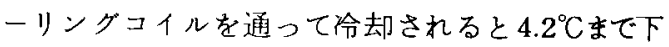
がり，実際に泩入される液温は5.0 ${ }^{\circ} \mathrm{C}$ 上䄯してい た又, $300 \mathrm{ml} / \mathrm{min}$ ではそれぞれ $5.5^{\circ} \mathrm{C}, 5.8^{\circ} \mathrm{C} て$ あった.（図2) 


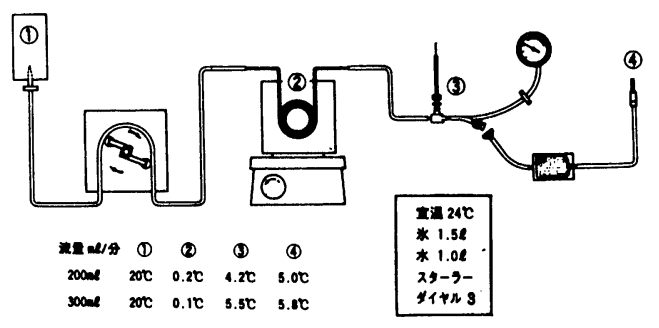

図 2 冷却モデル実験

表 1

\begin{tabular}{|c|c|c|c|c|}
\hline \multicolumn{2}{|c|}{ 疾息別使用症例数 } & \multicolumn{2}{|c|}{ 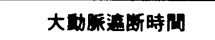 } & \\
\hline 先天性心疾学 & 19 侧 & $\sim 60$ 分 & 6 例 & \\
\hline 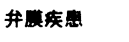 & 17 例 & $61 \sim 120$ 分 & 17 例 & \\
\hline 冠就后疾急 & 9 例 & $121 \sim 180$ 分 & 15 侧 & \\
\hline \multirow[t]{2}{*}{ st } & 46 侧 & $181 \sim 240$ 分 & 6 侧 & 22 例 \\
\hline & & 241 分 & 1 甽 & \\
\hline
\end{tabular}

\section{$<$ 症 例 $>$}

次に，このCCAS 回路システムを先天性心疾 患 19 例, 弁膜筷患 17 例, 冠動脈疾患 9 例飞, 実 際に臨床使用した。これを大動脈遮断時間別にみ ると, 60 分まで 6 例, 61 120 分まで 17 例, 遮 断 2 時間以上のものは 22 例であった。（表 1 ）

\section{<総 括 $>$}

45 症例の臨床使用では，心筋保護に特別問題 となることはなかったが，2，3 の注意すべき点が あった. 1 つは、スターラーの回転を最高にする と, 時折り共振し, 摜拌による冷却効果が低くな ることであった，它のためにわれわれは，スター ラーの回転をダイヤル 3 亿して共振を防止してい る. 次に，われわれは心筋保護液を 20 分毎に注入 しているが，注入終了から次の注入までの間に， クーリンクコイルからニードルアダプターまでの 回路内の液は, 約 $18{ }^{\circ} \mathrm{C}$ まで年する. 約 $4{ }^{\circ} \mathrm{C}$ の心 筋保護液を注入するためには，この上䄯した回路 内の液を捨てねばならず，その量は 1 回に約 $50 \mathrm{cc}$ になるので，予想遮断時間に合せ，この量も計算 して用意しなければならない，一方この CCAS 回路システムは, シングルパス冷却で, 冷却能が すぐれており，リサキュレーションが不要である. 又, 注入温度, 注入圧をモニタ一でき, 0.8 ミクロ
ンのフィルターが付いており回路の充填時に空気 抜きのわずらわしさがなく，簡単に使用でさるな ど利点がある。（表 2 ）

\section{表 $2 \mathrm{CCAS}$ 回路の特徵と使用上の注意点}

\begin{tabular}{|c|c|}
\hline 特 & 注害虎 \\
\hline 1, 命㭏能加すぐれている。 & 1，スターラーの井滑 \\
\hline 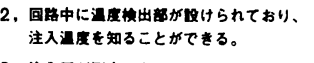 & 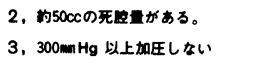 \\
\hline  & 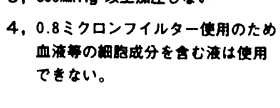 \\
\hline $\begin{array}{l}\text { 5. シングルバス命却であり、リサキュレー } \\
\text { ションが不曼 }\end{array}$ & \\
\hline
\end{tabular}

くまとめ $>$

このCCAS 回路システムを 45 症例飞奉際臨床 使用したが，心筋保護に特別問題となることがな く，心筋保護回路として，充分臨床に使用できる ことを確認した。

\section{参考文献}

1）黒田広ら：われわれの行なっている心筋保護 回路について, 体外循環技術, 6：59, 1980.

質問(1) 小松島日赤 坂東 正章

Cardiopiegia を流したときのPressureいくら位 い炈な

質問(2) 泉工医科工業秼) 西村 孝雄

注入される際，どれ位の注入圧で何ccで何分で 入れられるのか?

回答市立旭川病院黒田広

(1) 注入圧は, 圧力計で $100 \mathrm{~mm} \mathrm{Hg}$ であり,クーリ ングコイルからニードルアダプターまでの圧 損は約 $40 \mathrm{~mm} \mathrm{Hg}$ である. ですから，実際の注 入圧は約 $60 \mathrm{~mm} \mathrm{Hg}$ である.

(2) 初回量 $10 \mathrm{ml} / \mathrm{kg}$, 追加は 20 分毎で $5 \mathrm{ml} / \mathrm{kg}$ の 量である.

注入に要する時間は，压制御であり，注入王 制御で100 m $\mathrm{mg}$ を越えないようにしているの で, 注入時間は症例飞よって違う。 